\title{
Productivity of Jute Influenced by Some Major Climatic Variables in South -Western Coastal Region of Bangladesh
}

\author{
M. M. Islam ${ }^{1 *}$, M. A. Farukh², M. A. Baten ${ }^{2}$ \\ ${ }^{1}$ Department of Environmental Technology, Sherpur Polytechnic Institute, Bhatshala, Sherpur-2100, Bangladesh \\ ${ }^{2}$ Department of Environmental Science, Bangladesh Agricultural University, Bangladesh
}

Submission: April 15, 2020 ; Published: May 14, 2020

*Corresponding author: M. M. Islam, Department of Environmental Technology, Sherpur Polytechnic Institute, Bhatshala, Sherpur-2100, Bangladesh

Abstract

Due to be in disaster prone geographic area because of climate change, Bangladesh is one of the vulnerable largest deltas in the world. Agriculture is the main influential factor for Bangladesh economy. Jute and various vendible of jute are good sources of earning foreign currency of Bangladesh. But in the last decades it seems that our Agricultural sector especially coastal belt has been affected drastically by climate change. It is to scientifically assess the vulnerability of the golden fibre of Bangladesh; Jute production due to the unfavourable climatic variables fluctuation in South Western coastal belt, a original field research has been done considering the influential climatic factors of temperature, rainfall, humidity, sun shine hours and sea level pressure of last 30 years (1981-2011) and their impacts on the production of Jute. During the producing season of Jute, it has been increased the maximum and average temperature. And it was about unchanged pattern of sea-level pressure of here but the most important factor for production rainfall has been increased by 53, 12 and 142 mm in Khulna, Satkhira, Bagerhat respectively. The production proclivity of the jute shows most of the time as increasing except in Khulna in 2009 it was affected by demolishing natural disaster; AILA, so the production was drastically felled down in 2009.

Keywords: Productivity; Jute; Climatic variables; Coastal Belt; Bangladesh

\section{Introduction}

Bangladesh is a South Asian country included in Indian subcontinent holding $143,999 \mathrm{Km} 2$. The location of our country is between $20^{\circ} 34^{\prime}$ and $26^{\circ} 33^{\prime} \mathrm{N}$ latitude and between $88^{\circ} 01^{\prime}$ and $92^{\circ} 41^{\prime} \mathrm{E}$ longitude. Inland and estuarine water surface are a major feature in here. Most of the land of the country is flat which is orderly washed by water whether it is rain or flood. Various ultra-factors of climate change affect Bangladesh resulting the increasing vulnerability of the country. Now it is the alarm and wavering mode that the physical and natural system of Bangladesh will be changed due to the influence of climate change. It is assumed that 70 million people may be affected by climate change. High population density, poor infrastructure, high level of poverty, geographic location, low elevation and dependency on natural resources are the main key factors contributing to coastal vulnerability. Climatic variability and its change severally affect the coastal resources upon which most of the littoral people. It is predicted that about $15 \%$ of the country land area will be inundated for $45 \mathrm{~cm}$ rise of sea level by the year 2050, as a result of these about 35 million people will be migrated from coastal belt. Climate change is an unavoidable fact and a great future worry for all over the world. Many bad impacts of climate change including conclusive variability are already noticed to us. The Fourth Assessment Report (AR4) of Intergovernmental Panel on Climate Change [1] has reported that in the last century the global surface temperature has been increased by $0.74^{\circ} \mathrm{C}$. The sea level rose It is also $1.8 \mathrm{~mm}$ per year over 1961-2003 and mountain glaciers and snow cover have decreased on average in both south and northern hemisphere. In the last thirty years Bangladesh has been experienced the higher temperature [2]. Beside this, it is also predicted to face the rise in yearly mean temperatures of $1.0^{\circ} \mathrm{C}$, $1.4^{\circ} \mathrm{C}$ and $2.4^{\circ} \mathrm{C}$ by 2030,2050 and next 2100 respectively [3].

In the running era climate change poses significant risks for Bangladesh especially the coastal belt, yet the core elements of its vulnerability are primarily contextual. However, the Global Climate Model (GCM) data estimated more warming for winter than for the summer months [4]. Though monsoon season's rainfall is projected to increase; the rainfall variability may increase significantly causing more intense rainfall and/or longer dry spells. Most of the 
climate models estimated that precipitation will increase during the summer monsoon [5]. The maximum mean temperature observed in coastal belt is about $32^{\circ} \mathrm{C}$ to $38^{\circ} \mathrm{C}$ during the month of April, May, June and the minimum temperature recorded in January is about 7 to $16^{\circ} \mathrm{C}$. The highest rainfall is observed during the month of monsoon here. The annual average rainfall in the division is about $1250 \mathrm{~mm}$ [6]. This area is highly vulnerable to sea level rise, as it is a densely populated coastal country of smooth relief comprising broad and narrow ridges and depressions [7]. Between $30-70 \%$ of the country is normally flooded each year [8]. Production of crops depends on different types of weather parameters and phenomenon. Crop failure may sometimes occur due to excess and deficit rainfall conditions or flood or drought or unfavorable temperate condition of the country. Most of the areas of our country are within an inch prone to ambivalent impacts of climate change and coastal belts are especially very sensitive because of separate geo-environmental climatic situation. The coastal areas surrounded about one fifth of the total country area and occupies one-third of the total living organism of the country [9]. Various types of human interference are the main culprit causing the increasing mode of vulnerability [10]. The uprising demands of food for growing human population and declining trends of agricultural lands because of their accommodation affects the Bangladesh Agriculture negatively [11]. About 80 percent of the Bangladesh population is living in village area and 90 percent of this population are actively associated with the Agricultural farming activity [12]. In spite of the modern steps concerning to reach the sustainable development, Bangladesh's proficiency to compensate its uplift is experienced with effective challenges and confounded by climate change [11]. Khulna division is one of the seven divisions of Bangladesh and is in the south-west of the country. The climate of Khulna division is generally marked with monsoons, high temperature, considerable humidity and moderate rainfall. The hot season commence early in March and continues till the middle of July.

In Khulna division most of the people depends directly or indirectly on agricultural products for their living. A major part of Khulna division is covered by coastal zone which is directly vulnerable and sensitive to climate change. In this piece of research, it is tried to find the changing trend of major climatic variables and their interference on jute as a major economic crop production in Khulna division. In Bangladesh, many researches have been done to assess the trend and pattern of temperature, rainfall, relative humidity, solar radiation, heat budget and energy balance on different ecosystem and meteorological impacts on Jute production. But past records prevailed that very few studies have done to analysis the relationship between changes in the climatic variables with Jute productivity in Southern coastal part of Bangladesh. Under this circumstance a research was conducted to identify the effects of changing climatic factors on Jute production in South-Western coastal belt of Bangladesh.

\section{The Specific Objectives of the Study are to:}

i). describe the fluctuating trends of some major climatic factors during Jute season.

ii). climate change impacts on the acquiring the amount of production area, and;

iii). finally, how the Jute productivity was affected with the changing pattern of climatic variables?

Hypotheses of the Study are stated as:

H01: There is a significant association between humidity and jute productivity in study area, but;

H02: There is no significant relationship between other climatic factors and jute productivity in study area.

\section{Materials and Methods}

\section{Study area}

For this piece of research, it is considered the three major South-Western coastal districts Khulna, Satkhira, Bagerhat as the study area. Khulna district lies in the southern part of the country between $22^{\circ} 12^{\prime}$ and $23^{\circ} 01^{\prime}$ North latitudes and $89^{\circ} 14^{\prime}$ and $89^{\circ} 45^{\prime}$ East longitudes. In respect of the districts ranks it was 1st among 16 districts of Khulna division and 3rd among 64 districts of the country (BBS, 1985). Satkhira district situated in the south west corner of the country between $21^{\circ} 38^{\prime}$ and $22^{\circ} 57^{\prime}$ North latitudes and $88^{\circ} 54^{\prime}$ and $88^{\circ} 58^{\prime}$ East longitudes. Bagerhat district lies in the southern part of the country between $22^{\circ} 13^{\prime}$ and $22^{\circ} 59^{\prime}$ North latitudes and $89^{\circ} 32^{\prime}$ and $89^{\circ} 58^{\prime}$ East longitudes (Figure 1). Data Collection and analysis

After completion of collecting data, they were compiled, tabulated and analyzed according to the objective of the research. Daily average climatic data such as maximum temperature $\left({ }^{\circ} \mathrm{C}\right)$, average temperature $\left({ }^{\circ} \mathrm{C}\right)$, daily total rainfall $(\mathrm{mm})$, average humidity (\%), and daily sea level pressure ( $\mathrm{mb}$ ) at three stations such as Khulna, Satkhira, and Bagerhat of Khulna division for the period of January 1980 to December 2011 (i.e. 31 years) were used in this study. Data were collected from Bangladesh Meteorological Department (BMD). It is very important to allusion that there were some default data in some days of various years. To maintain the continuity, the gaps were filled up by the time mean values of the existing years. The annual Jute production data have been collected from Yearbook of Agricultural Statistics of Bangladesh from 1980 to 2012. Data were organized and put in MS excel and SPSS for statistical analyze. Annual average and total measurement of the variables (temperature, relative humidity, rainfall and sea level pressure) of the selected stations of Bangladesh were calculated to analyze the trend and their correlation with production ( $\mathrm{t}$ ha1) of each Jute from 1981 to 2011 . The regression equations and the coefficient of determination (R2) have been obtained through scatter diagrams by taking two indices at a time. 


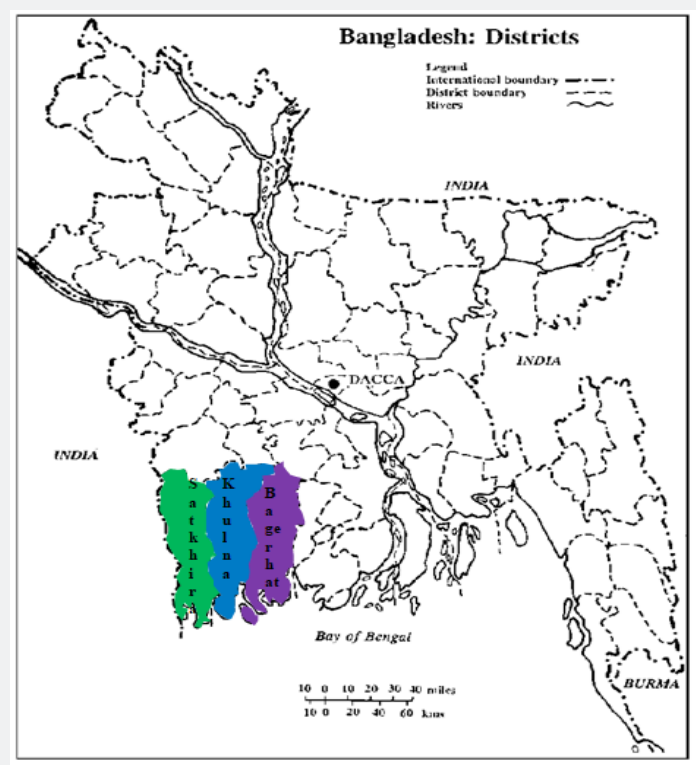

Figure 1: Map of Bangladesh with marked study area.

Results and Discussion

\section{Seasonal Jute productivity and climatic variables}
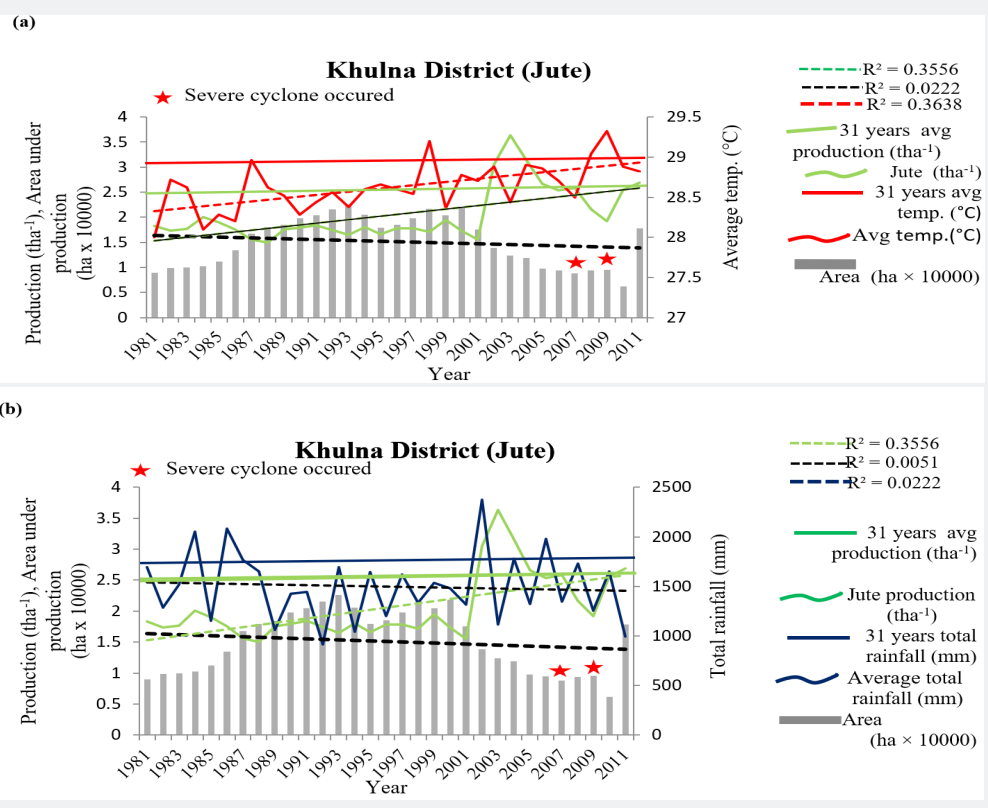

Figure 2: Inter Seasonal variability of Jute production (tha-1) with area influenced by (a) average maximum temperature $\left({ }^{\circ} \mathrm{C}\right)(\mathrm{b})$ total average rainfall $(\mathrm{mm})$ at Khulna district during 1981-2001.

\section{In Khulna}

It was found from the Figure 2 that the Jute production (tha1) showed increasing trend at Khulna district during 1981-2011. And the production area (ha) was increased from 1981-2000 then it was decreased till 2010. The average annual Jute production and area was 2.05 (tha-1) and 1.52 hectares respectively. The annual average production level (2.05tha-1) of Jute exceeded downward to the trend line of production in 1999. In 2003, the production (tha-1) of Wheat reached a peak of 3.36 (tha-1) and it was reached at bottom of 1.55 (tha-1) in 2001 in Khulna district. Figure 2 (a) 
also showed that the yearly monsoon daily maximum temperature showed the increasing trend at Khulna district during 1981-2011. The co-efficient of determination (R2) of maximum temperature was 0.022 indicated that the change was significant and partially alarming to climate change. Both the maximum temperature $\left({ }^{\circ} \mathrm{C}\right)$ and the annual Jute production (tha-1) were increasing gradually indicate slight inclining temperature trend is not unfavorable for the production at all. The trend line of yearly seasonal daily maximum temperature crossed to the corresponding average value in 1997. It was found from the Figure 2 (b) that the seasonal rainfall showed the liner fit trend line hardly affecting production rate of Jute from 1981-2011 in Khulna district. The Average total seasonal rainfall was $1498 \mathrm{~mm}$ during Jute season in Khulna district from 1981-2011.

\section{In Satkhira}

It was found from the Figure 3 that the Jute production (tha-1) showed linearly fit trend at Satkhira district during 1981-2011. And the production area (ha) was gradually decreased from 1981-2010 and in 2011 it was increased that may be the causes of increasing price Jute in nowadays. The production of jute was increased by $0.85,0.21$ and 0.20 tha- 1 in Khulna, Satkhira and Bagerhat respectively. The average annual Jute production and area was 2.74 (tha-1) and 0.961 hectares in some respects in the study area. The Figure 3(a) showed that the annual monsoon daily average temperature showed the decreasing trend respectively in Satkhira district during 1981-2011. The difference between the average temperature from 1981 to $1988\left(29.87^{\circ} \mathrm{C}\right)$ and 1989 to $2011\left(29.19^{\circ} \mathrm{C}\right)$ decreased by $0.68^{\circ} \mathrm{C}$ by Jute season in Satkhira district. The co-efficient of determination (R2) of daily average temperature was 0.099 indicated that the change was significant and partially influencing to climate change. The average temperature $\left({ }^{\circ} \mathrm{C}\right)$ during the season of Jute was $29.350 \mathrm{C}$. The trend line of annual monsoon daily average temperature exceeded to downward to the corresponding average value in 1982. It was found from the Figure 3(b) that the seasonal total rainfall showed the slightly inclining trend adversely affecting production rate of Jute from 1981-2011 in Satkhira district. The Average total seasonal rainfall was $1492.03 \mathrm{~mm}$ in Jute season.

(a)

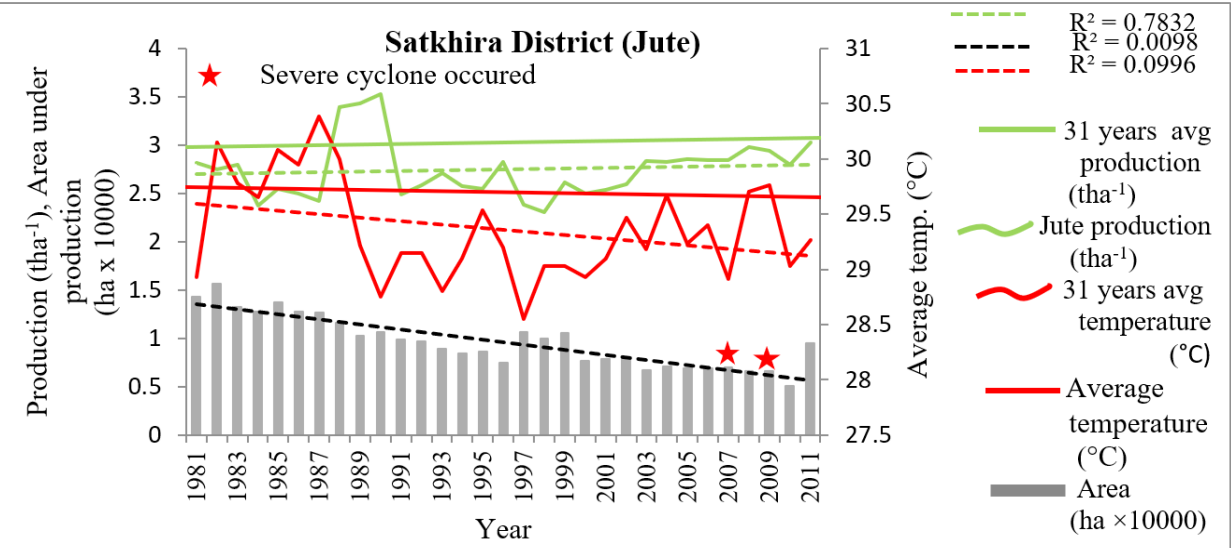

(b)
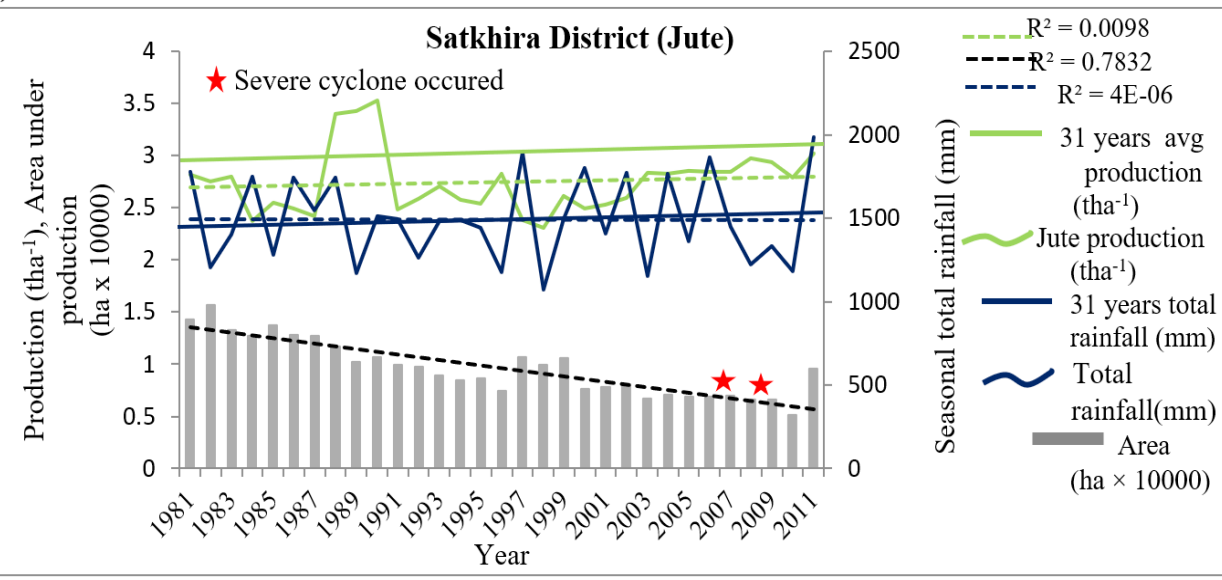

$($ ha $\times 10000)$

Figure 3: Inter Seasonal variability of Jute production (tha-1) with area influenced by (a) average temperature $\left({ }^{\circ} \mathrm{C}\right)(\mathrm{b})$ total average rainfall $(\mathrm{mm})$ at Satkhira district during 1981-2001. 


\section{In Bagerhat}

It was found from the Figure 4 that the Jute production (tha-1) showed slightly decreasing trend at Bagerhat district during 19812011. And the production area (ha) was also gradually decreased from 1981-2010. The average annual Jute production and area was 3.01 (tha-1) and 1.28 hectares respectively. The annual average production level (3.01 tha-1) of Jute exceeded upward to the trend line of production in 1993. In 2011, the production 3.02 tha- 1 of Jute reached a peak of tha- 1 and it was reached at bottom of 2.38 tha-1 in 1996 in Bagerhat district. The Figure 4 (a) showed that the annual monsoon maximum temperature showed the uplifting trend at Bagerhat district during 1991-2011. The previous data of temperature was not found in source. The co-efficient of determination (R2) of daily maximum temperature was 0.402 also indicated that the change was significant and partially alarming to climate change. With the both inclining trends of maximum temperature and the annual production (tha-1) indicates slight increasing of temperature is not unfavorable for the production at all. The trend line of annual monsoon daily average maximum temperature exceeded to upward to the corresponding average value in 2001. From the Figure 4(b) it is found that the average monsoon daily sea level pressure showed the gradually decreasing trend with some fluctuations in Jute season at Bagerhat district during 1991-2011. The average value of sea level pressure was $1002.77 \mathrm{mb}$ during Jute season from 1989-2011in Bagerhat district.

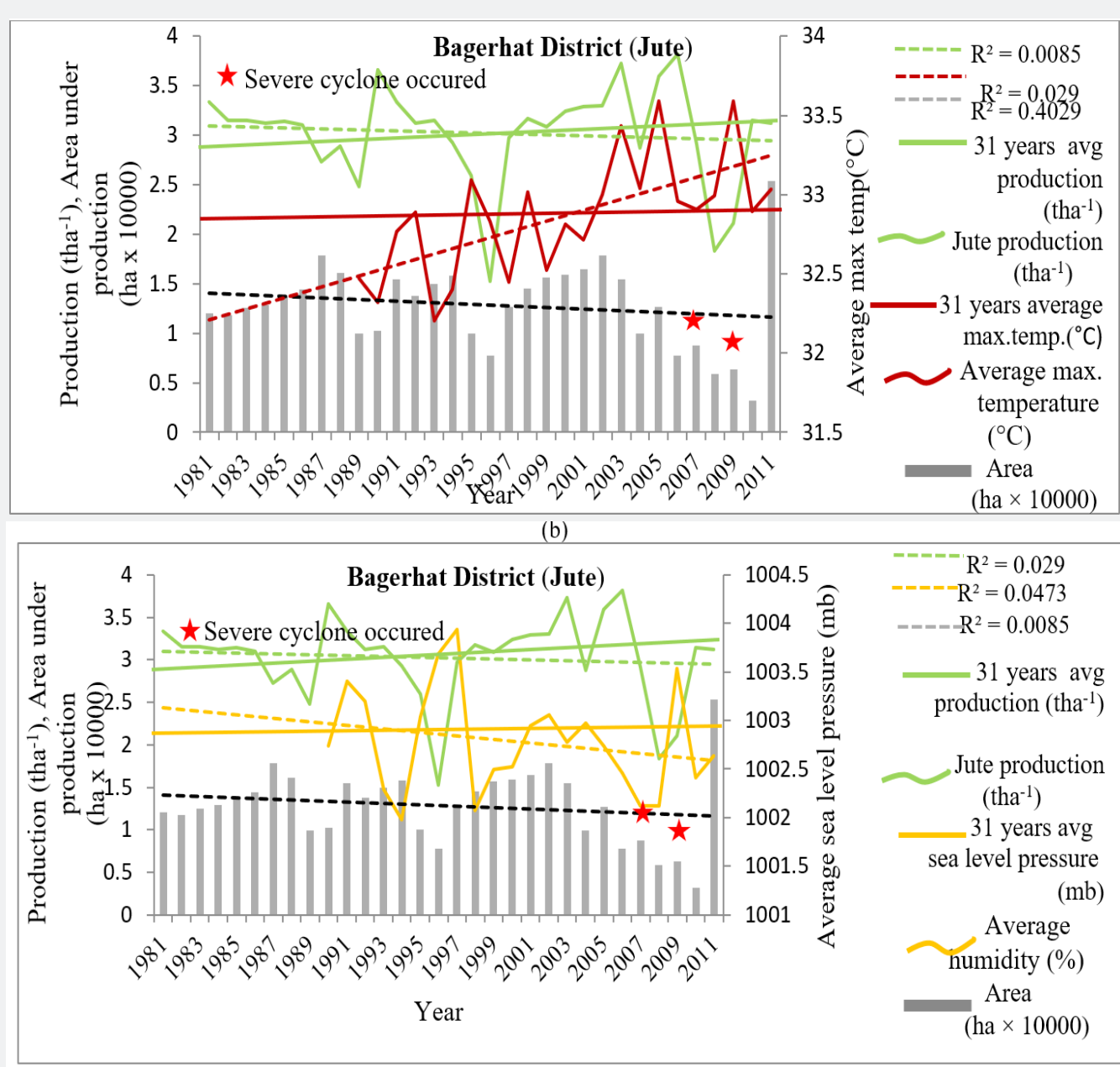

Figure 4: Inter Seasonal variability of Jute production (tha-1) with area influenced by (a) average maximum temperature $\left({ }^{\circ} \mathrm{C}\right)(\mathrm{b})$ total average sea level pressure at Bagerhat district during 1981-2011.

Relationship between production (tha-1) and climatic factors of Jute in different region

The computed correlation co-efficient between production of Jute (tha-1) and average humidity over Khulna district was 0.389 as shown in (Table 2). The flowing observations were made concerning the relationship between these two variables from (Figure 5) and (Table1) 


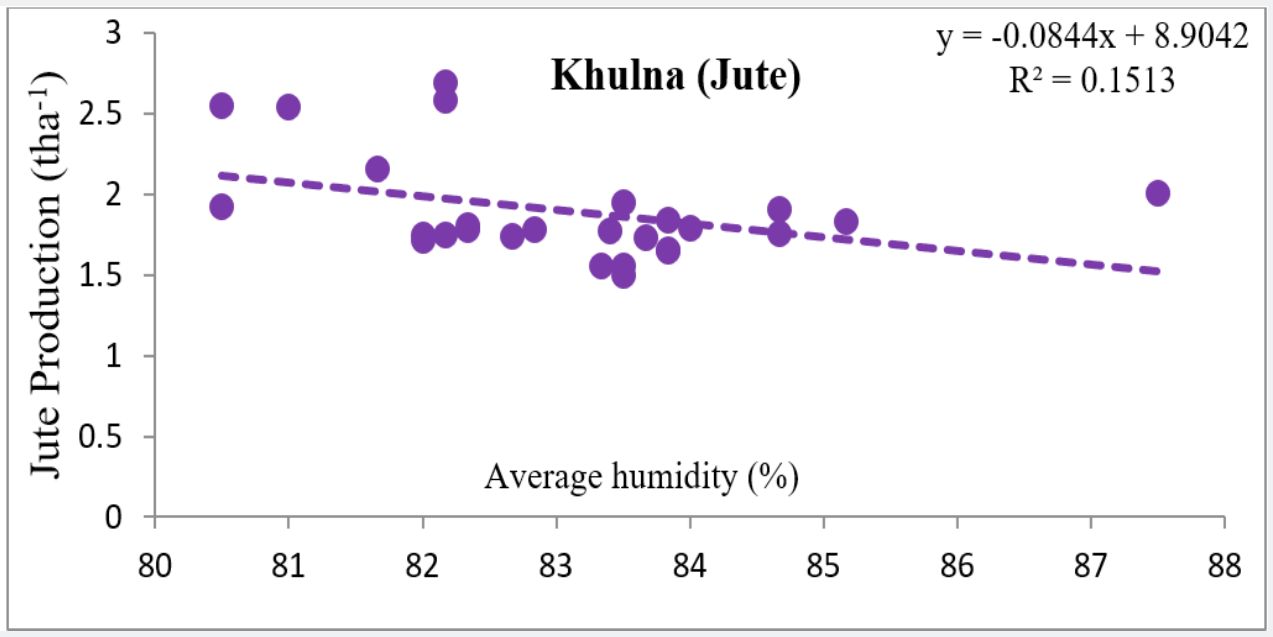

Figure 5: Relationship between Jute production (tha-1) and average humidity (\%) in Khulna district during 1981-2011.

a) The relationship showed a negative and downward trend.

b) The average humidity showed medium influence on Jute production.

c) The computed value of $r(0.389)$ was found to be greater than that of the tabulated value at 0.01 level of probability. The computed correlation co-efficient between Jute production (tha-1) and average humidity over Bagerhat district was 0.445 as shown in (Table 1). The flowing observations were made concerning the relationship between these two variables from (Figure 6) and (Table 1)

a) The relationship showed a positive and upward trend.

b) The average humidity showed lower influence on Jute production.

c) The computed value of $\mathrm{r}(0.445)$ was found to be greater than that of the tabulated value at 0.01 level of probability

Table 1: Significant Correlation for Jute.

\begin{tabular}{|c|c|c|c|c|c|}
\hline \multirow{2}{*}{ District / Year } & & Characteristics corrected & $\begin{array}{c}\text { Determination of Co-effi- } \\
\text { cient (R2) }\end{array}$ & $\begin{array}{c}\text { Correlation co-effi- } \\
\text { cient } ®\end{array}$ & $\begin{array}{c}\text { Level of signifi- } \\
\text { cance }\end{array}$ \\
\hline Khulna & $1981-2011$ & Havg Vs P & 0.151 & $0.389\left(^{*}\right)$ & 0.01 \\
\hline Bagerhat & $1981-2011$ & Havg Vs P & 0.198 & $0.445\left(^{*}\right)$ & 0.01 \\
\hline
\end{tabular}

Where, $\mathrm{P}=$ Production (tha- 1 ), Havg = Average Humidity, $\left.{ }^{(*}\right)$ means significant at $1 \%$ level.

\section{Conclusion}

The climatic variables were changed by both decreasing and increasing trends but most of the Jute productions were increased here. In Khulna district during Jute season the seasonal daily average and maximum temperature were increased respectively by $0.62^{\circ} \mathrm{C}$ and $1.59^{\circ} \mathrm{C}$ during $1981-2011$. During this period in Satkhira district the average temperature from 1981 to 1988 $\left(29.87^{\circ} \mathrm{C}\right)$ and 1989 to $2011\left(29.19^{\circ} \mathrm{C}\right)$ decreased by $0.68^{\circ} \mathrm{C}$ and the humidity increased by $3.7 \mathrm{~mm}$, but the rainfall was linearly fit from 1981 to 2011. Average humidity has negative and downward relation with Jute production in Satkhira district where in Bagerhat we found the positive and upward relation with Jute Production.
The both average and maximum temperature increased but humidity and sea level pressure decreased gradually in Bagerhat during Jute Season. The area of Jute production was increased from 1981 to 2000 and after that it was gradually decreased till 2010 in Khulna district.

\section{Acknowledgement}

The authors are grateful for conducive activity of Bangladesh Burro of Statistics (BBS) for giving the crop production data and to Bangladesh Meteorological Department (BMD) for providing climatic data. They would like to thank professors and friends who helped them 


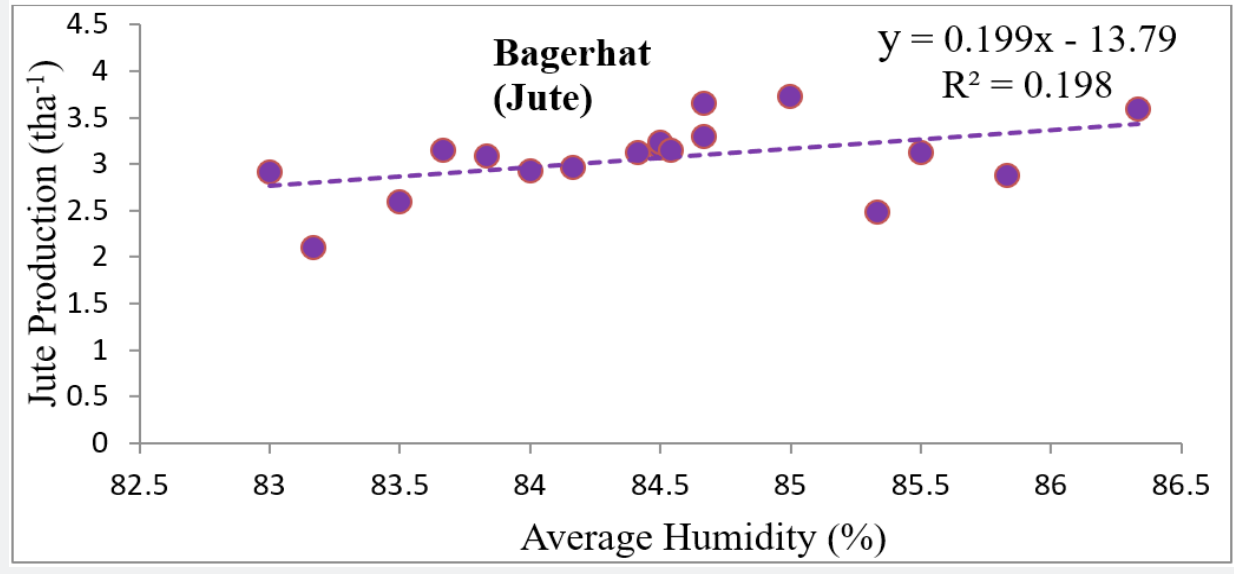

Figure 6: Relationship between production of Jute (tha-1) and average humidity (\%) in Bagerhat during 1981-2011.

\section{References}

1. IPCC, Climate Change 2007: the physical science basis. In: Solomon S Quin D, Manning M, Chen X, Marquis M, Averyt KB, Tignor HL, Miller $M$ (eds) Contribution of Working Group I to the Fourth Assessment Report of the Intergovernmental Panel on Climate Change. Cambridge University Press, Cambridge, pp 1-996.

2. Sarker MAR, Alam K, Gow J (2012) Exploring the relationship between climate change and rice yield in Bangladesh.

3. Agrawala STO, Ahmed AU, SmithJ, Aalst MV (2003) Development and Climate Change in Bangladesh: Focus on Coastal Flooding and the Sunderbans; Organisation for Economic Co-operation and Development (OECD): Paris, France.

4. Food and Agriculture Organization (FAO) (2007) Climate Variability and Change: Adaptation to Drought in Bangladesh. In A Resource Book and Training Guide; FAO: Rome, Italy,

5. Mirza MMQ (1997) Modeling the Effects of Climate Change on Flooding in Bangladesh. Ph.D. Thesis, International lobal Change Institute (IGCI), University of Waikato, Hamilton, New Zealand,

6. BBS (Bangladesh Bureau of Statistics) (2012) Statistical Yearbook of Bangladesh. Statistics division, Ministry of Planning, Government of the Republic of Bangladesh pp. 187-199.
7. Brammer H, Asaduzzaman M, Sultana P, (1993) Effects of Climate and Sea-level Changes on the Natural Resources of Bangladesh. Briefing Ducument No. 3, Bangladesh Unnayan Parishad (BUP), Dhaka.

8. Ahmed AU, Alam M (1998) Development of Climate Change Scenarios with General Circulation Models. In Vulnerability and Adaptation to Climate Change for Bangladesh; Huq S, Karim Z, Asaduzzaman M, Mahtab F, Eds. Kluwer Academic Publishers: Dordrecht, The Netherlands, pp. 13-14.

9. Hassan A, MAR Shah, (2009): Impact of sea level rise on suitability of agriculture and fisheries: A case

study on Southwest Region of Bangladesh. Center for Environmental and Geographic Information Services (CEGIS), Dhaka, Bangladesh.

10. Miah MGU, MN Bari, SMF Islam, T Ahamed, A Rahman, (2009): Impacts of Anthropogenic activities on natural resources and food security in the coastal region of Bangladesh. Project Final Report. NFPCSP/FAO/ USAID/EC. Dhaka, Bangladesh.

11. Ahmed A, Ryosuke S (2000) Climate change and agricultural food production of Bangladesh: an impact assessment using GIS-based biophysical crop simulation model. Center for Spatial Information Science, University of Tokyo, 4-6 Komaba, Japan.

12. Bangladesh-Economic-Review -2009, Finance Division, Ministry of Finance, Government of People's Republic of Bangladesh.
Your next submission with Juniper Publishers will reach you the below assets

- Quality Editorial service

- Swift Peer Review

- Reprints availability

- E-prints Service

- Manuscript Podcast for convenient understanding

- Global attainment for your research

- Manuscript accessibility in different formats

( Pdf, E-pub, Full Text, Audio)

- Unceasing customer service

Track the below URL for one-step submission https://juniperpublishers.com/online-submission.php 